\title{
Recent insights into the molecular mechanisms of the NLRP3
}

\section{inflammasome activation [version 1; peer review: 2 approved]}

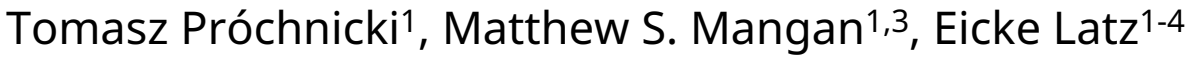 \\ ${ }^{1}$ Institute of Innate Immunity, University Hospital, University of Bonn, Bonn, Germany \\ 2Department of Infectious Diseases and Immunology, University of Massachusetts Medical School, Worcester, MA, USA \\ ${ }^{3}$ German Center for Neurodegenerative Diseases, Bonn, Germany \\ ${ }^{4}$ Centre of Molecular Inflammation Research, Norwegian University of Science and Technology, Trondheim, Norway
}

V1 First published: 22 Jun 2016, 5(F1000 Faculty Rev):1469

https://doi.org/10.12688/f1000research.8614.1

Latest published: 22 Jun 2016, 5(F1000 Faculty Rev):1469

https://doi.org/10.12688/f1000research.8614.1

\section{Abstract}

Inflammasomes are high-molecular-weight protein complexes that are formed in the cytosolic compartment in response to danger- or pathogen-associated molecular patterns. These complexes enable activation of an inflammatory protease caspase-1, leading to a cell death process called pyroptosis and to proteolytic cleavage and release of pro-inflammatory cytokines interleukin (IL)-1 $\beta$ and IL-18. Along with caspase-1, inflammasome components include an adaptor protein, ASC, and a sensor protein, which triggers the inflammasome assembly in response to a danger signal. The inflammasome sensor proteins are pattern recognition receptors belonging either to the NOD-like receptor (NLR) or to the AIM2-like receptor family. While the molecular agonists that induce inflammasome formation by AIM 2 and by several other NLRs have been identified, it is not well understood how the NLR family member NLRP3 is activated. Given that NLRP3 activation is relevant to a range of human pathological conditions, significant attempts are being made to elucidate the molecular mechanism of this process. In this review, we summarize the current knowledge on the molecular events that lead to activation of the NLRP3 inflammasome in response to a range of $\mathrm{K}^{+}$efflux-inducing danger signals. We also comment on the reported involvement of cytosolic $\mathrm{Ca}^{2+}$ fluxes on NLRP3 activation. We outline the recent advances in research on the physiological and pharmacological mechanisms of regulation of NLRP3 responses, and we point to several open questions regarding the current model of NLRP3 activation.

Keywords

Inflammasome, pyroptosis, NLRP3, autoinflammatory disease

\section{Open Peer Review}

Approval Status

1

2

version 1

22 Jun 2016

Faculty Reviews are review articles written by the prestigious Members of Faculty Opinions. The articles are commissioned and peer reviewed before publication to ensure that the final, published version is comprehensive and accessible. The reviewers who approved the final version are listed with their names and affiliations.

1. Pablo Pelegrín, University Hospital Virgen de la Arrixaca, Murcia, Spain

2. George Dubyak, Case Western Reserve

University, Cleveland, USA

Any comments on the article can be found at the end of the article. 
Corresponding author: Eicke Latz (Eicke.latz@uni-bonn.de)

Competing interests: The authors declare that they have no competing interests.

Grant information: The author(s) declared that no grants were involved in supporting this work.

Copyright: @ 2016 Próchnicki T et al. This is an open access article distributed under the terms of the Creative Commons Attribution License, which permits unrestricted use, distribution, and reproduction in any medium, provided the original work is properly cited.

How to cite this article: Próchnicki T, Mangan MS and Latz E. Recent insights into the molecular mechanisms of the NLRP3 inflammasome activation [version 1; peer review: 2 approved] F1000Research 2016, 5(F1000 Faculty Rev):1469

https://doi.org/10.12688/f1000research.8614.1

First published: 22 Jun 2016, 5(F1000 Faculty Rev):1469 https://doi.org/10.12688/f1000research.8614.1 


\section{Direct activation of NLRP3 by $\mathrm{K}^{+}$efflux}

The stimulatory effect that cytosolic $\mathrm{K}^{+}$depletion has on IL- $1 \beta$ proteolytic processing and secretion from LPS-primed macrophages and monocytes, in response to compounds such as ATP or nigericin, was observed long before the discovery of inflammasomes ${ }^{1-3}$. This effect is now known to be mediated by NLRP3 $3^{4}$, and $\mathrm{K}^{+}$efflux remains the best-characterized minimal stimulus for NLRP3 inflammasome activation ${ }^{5}$. Conversely, incubation in media containing supraphysiological $\left[\mathrm{K}^{+}\right]$can block NLRP3 inflammasome assembly in response to most of the identified NLRP3 triggers ${ }^{5}$.

The major classes of NLRP3 activators include extracellular ATP at millimolar concentrations, $\mathrm{K}^{+}$ionophores $^{4}$ and crystalline/ particulate substances, or other factors that cause lysosomal destabilization ${ }^{6,7}$. All of these stimuli are known to decrease the cytosolic level of $\mathrm{K}^{+}$ions ${ }^{5}$, but the mechanisms of $\mathrm{K}^{+}$efflux induction (summarized in Figure 1) differ for all classes of NLRP3 triggers. Before discussing these mechanisms in detail, it is important to reiterate some of the basic features of cellular $\mathrm{K}^{+}$homeostasis. Firstly, the cytosolic $\left[\mathrm{K}^{+}\right]\left(\left[\mathrm{K}^{+}\right]_{\mathrm{i}} ; \sim 140 \mathrm{mM}\right)$ is much higher than the extracellular $\left[\mathrm{K}^{+}\right]\left(\left[\mathrm{K}^{+}\right]_{\mathrm{e}} ; \sim 5 \mathrm{mM}\right)$, and this distribution is approximately reversed for $\mathrm{Na}^{+}$ions. This asymmetry is maintained by the $\mathrm{Na}^{+} / \mathrm{K}^{+}$-ATPase, an electrogenic ion pump transporting, during each cycle, two $\mathrm{K}^{+}$cations into the cytosol and three $\mathrm{Na}^{+}$cations into the extracellular milieu. Secondly, under basal conditions, the permeability of most mammalian plasma membranes is highest with respect to the $\mathrm{K}^{+}$cations and much lower for $\mathrm{Na}^{+}$and $\mathrm{Ca}^{2+}$. Together, these factors contribute to sustaining the transmembrane potential of mammalian cells, which is characterized by a slight excess of negative charge on the inside of the cell. Each cycle of the $\mathrm{Na}^{+} / \mathrm{K}^{+}$-ATPase produces an electric charge difference of one elementary unit, and slow leakage of $\mathrm{K}^{+}$ions from the cell is not counterbalanced by a compensatory influx of another type of cation $^{8}$. Plasma membranes in basal states can generally be regarded as electrical insulators ${ }^{9}$, so translocations of even small numbers of individual ions (much too small to cause any measurable changes in the intracellular concentration of the respective ion) produce significant changes in the value of transmembrane potential ${ }^{8}$. Similarly, transporting ions in the direction opposite to the electrical gradient (i.e. cations to the outside of the cell or anions into the cell) requires significant energy input. In this light, the dramatic decrease in $\left[\mathrm{K}^{+}\right]_{\mathrm{i}}$ required for NLRP3 activation, estimated as a drop of at least $\sim 20-30 \% \%^{5}$, can be expected to be accompanied by either a counter-flux of cations or a "co-flux" of anions, which should also be provided by NLRP3 stimuli.

Extracellular ATP at millimolar concentrations acts as an agonist of a ligand-gated cation channel called $\mathrm{P} 2 \mathrm{X} 7$ receptor (P2X7R), which is permissive to $\mathrm{K}^{+}, \mathrm{Na}^{+}$, and $\mathrm{Ca}^{2+10}$, allowing for cytosolic $\mathrm{K}^{+}$efflux balanced by the influx of extracellular $\mathrm{Na}^{+}$and $\mathrm{Ca}^{2+} \cdot \mathrm{K}^{+}$ ionophores activating the NLRP3 inflammasome provide diverse pathways for $\mathrm{K}^{+}$transport. Gramicidin, a peptide ionophore, allows for $\mathrm{K}^{+}$efflux balanced by $\mathrm{Na}^{+}$influx by inserting into plasma membranes to form monovalent cation $\left(\mathrm{Na}^{+} / \mathrm{K}^{+}\right)$-permissive pores ${ }^{11}$ in a manner electrochemically similar to the P2X7R. A different mechanism is employed by nigericin, a carboxylic ionophore that can exist in a free membrane-impermeant anionic form or as a neutral membrane-permeant complex when bound to a $\mathrm{K}^{+}$cation or a proton $\left(\mathrm{H}^{+}\right)$. In one electroneutral $\mathrm{K}^{+}$efflux cycle mediated by nigericin, the ionophore anion binds to $\mathrm{H}^{+}$on the outside of the cell, passes across the plasma membrane as nigericin- $\mathrm{H}$, and releases the proton on the intracellular side. There, nigericin anion binds to $\mathrm{K}^{+}$, which is subsequently transported across the plasma membrane as nigericin- $\mathrm{K}$ and released on the outside of the cell ${ }^{12}$. This mechanism facilitates $\mathrm{K}^{+}$efflux by allowing an $\mathrm{H}^{+}$influx, leading to acidification of cytosol. Valinomycin, another NLRP3-activating $\mathrm{K}^{+}$ionophore, also forms equimolar complexes with $\mathrm{K}^{+}$but, unlike the neutral nigericin- $\mathrm{K}$ complexes, these complexes have a single positive charge (valinomycin- $\left.\mathrm{K}^{+}\right)^{12}$. Therefore, valinomycinmediated $\mathrm{K}^{+}$efflux is electrogenic and can only occur until the chemical gradient that is pushing $\mathrm{K}^{+}$ions to the outside of the cell is balanced by the electric force drawing cations into the cell. It is currently unknown if such modest leakage of $\mathrm{K}^{+}$ions could be sufficient to activate NLRP3, or if the valinomycin-mediated $\mathrm{K}^{+}$efflux is accompanied by movement of another ionic species that would allow for a more pronounced decrease of $\left[\mathrm{K}^{+}\right]_{\mathrm{i}}$.

It has been demonstrated that cell treatment with crystalline/ particulate stimuli, representing pathophysiologically relevant NLRP3 activators, also leads to depletion of intracellular $\mathrm{K}^{+5}$. However, the mechanism by which crystal-induced $\mathrm{K}^{+}$efflux occurs is currently not understood. It seems plausible that, during lysosomal rupture caused by crystals, mixing of lysosomal lumina (low $\left[\mathrm{K}^{+}\right]$, close to the extracellular concentration ${ }^{13}$ ) with the cytosolic contents could passively decrease $\left[\mathrm{K}^{+}\right]_{i}$. However, the observation that the net $\mathrm{K}^{+}$content of cells decreases upon treatment with crystals ${ }^{5}$ suggests, in the absence of data on the values of $\left[\mathrm{K}^{+}\right]_{\mathrm{i}}$, that plasma membrane-resident $\mathrm{K}^{+}$channels or transporters might be involved in the crystal-elicited $\mathrm{K}^{+}$efflux. One model of NLRP3 activation by monosodium urate (MSU) crystals proposes that, upon phagocytosis, in the acidic lysosomal environment, $\mathrm{Na}^{+}$ions can be released from MSU particles leading to an increase in the osmolarity of the cell. This increase in osmolarity can be balanced by an influx of water from the extracellular space, which, it is suggested, dilutes $\left[\mathrm{K}^{+}\right]_{\mathrm{i}}$ and thereby triggers NLRP3 activation ${ }^{14}$. While the proposed mechanism explains how MSU crystal-induced lysosomal damage can activate the NLRP3 inflammasome, it cannot account for NLRP3 activation with stimuli such as silica or cholesterol crystals because these particles do not dissociate in the lysosomal $\mathrm{pH}$ and are consequently not expected to influence cellular osmolarity. Investigating the kinetics and molecular mechanism of $\mathrm{K}^{+}$loss in cells undergoing lysosomal damage may prove highly relevant for understanding how the different NLRP3 stimuli trigger inflammasome assembly and for designing treatments that specifically target NLRP3 activation by crystalline agents, which underlies multiple inflammatory diseases.

A number of other conditions that deplete cytosolic $\mathrm{K}^{+}$have been demonstrated to activate NLRP3. These include pharmacological inhibition of $\mathrm{Na}^{+} / \mathrm{K}^{+}$-ATPase ${ }^{3,5}$. Blocking $\mathrm{Na}^{+} / \mathrm{K}^{+}$-ATPase deprives cells of the mechanism maintaining both the asymmetric distribution of $\mathrm{Na}^{+}$and $\mathrm{K}^{+}$ions and the membrane potential, leading to a loss of $\mathrm{K}^{+}$ions. Under conditions of $\mathrm{Na}^{+} / \mathrm{K}^{+}$-ATPase inhibition, $\mathrm{K}^{+}$ ions are no longer actively imported by the cell. Furthermore, dissipation of membrane potential, which accompanies $\mathrm{Na}^{+} / \mathrm{K}^{+}$-ATPase inhibition, eliminates the electrical force drawing $\mathrm{K}^{+}$ions into the 


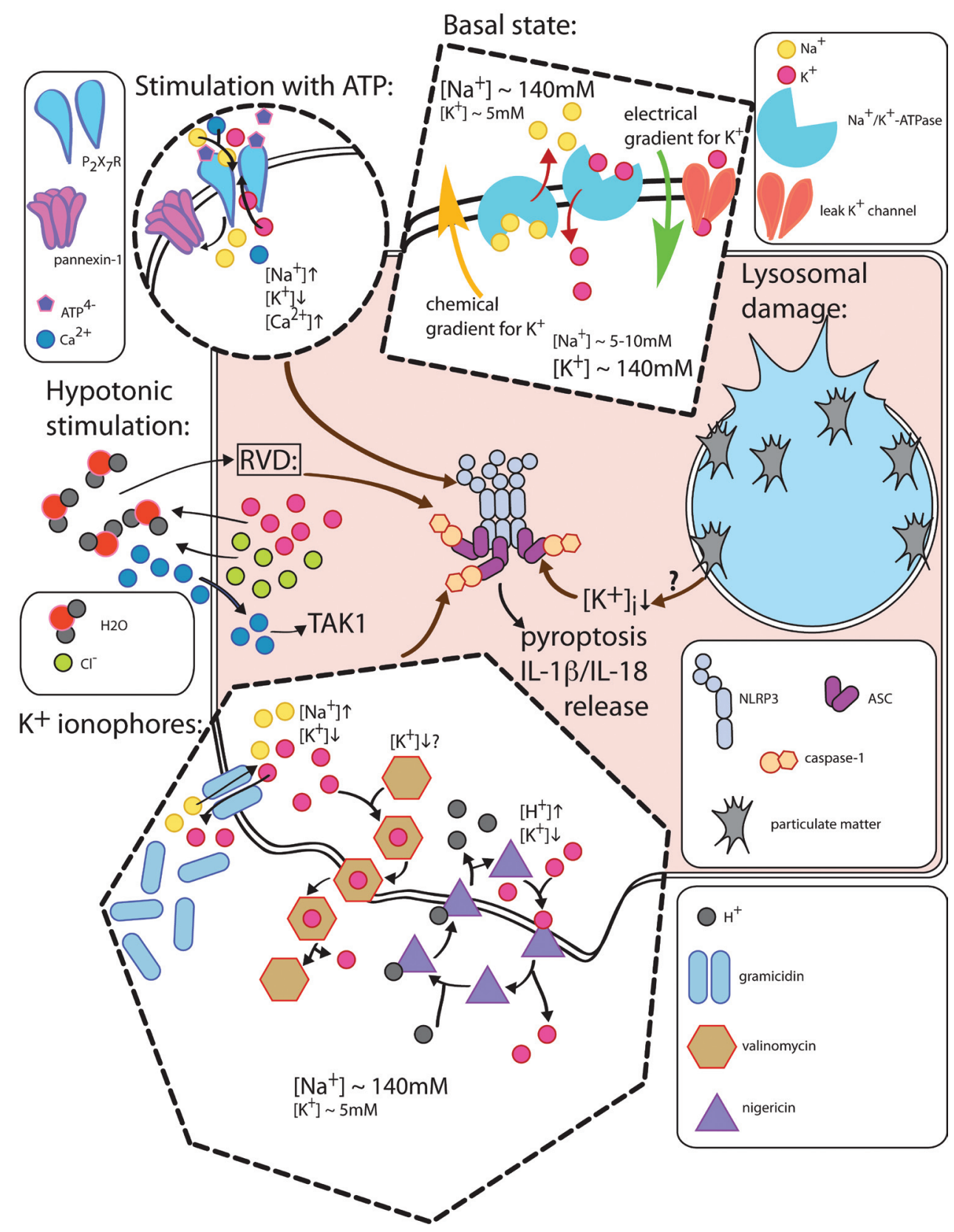

Figure 1. Canonical NLRP3 inflammasome activation by $\mathrm{K}^{+}$efflux. Under basal conditions, high intracellular $\mathrm{K}^{+}$concentration is maintained by the activity of $\mathrm{Na}^{+} / \mathrm{K}^{+}$-ATPase, which actively imports $\mathrm{K}^{+}$ions into the cell and generates an electrical gradient that favors movement of cations into the cytoplasm. Together with leak $\mathrm{K}^{+}$channels, $\mathrm{Na}^{+} / \mathrm{K}^{+}$-ATPase contributes to the transmembrane potential, characterized by a slight excess of negative charges inside the cell. Under conditions of NLRP3 stimulation, this equilibrium is disturbed. ATP increases the open probability of P2X7R, a cation channel that allows for net exchange of intracellular $\mathrm{K}^{+}$ions for extracellular $\mathrm{Na}^{+}$or $\mathrm{Ca}^{2+}$ ions. This produces a net $\mathrm{K}^{+}$efflux that acts as an NLRP3 activator. Activation of P2X7R is also accompanied by opening of pannexin-1 channels. During hypotonic stimulation, the regulatory volume decrease (RVD) response causes opening of $\mathrm{K}^{+}$and $\mathrm{Cl}^{-}$channels, driving an efflux of $\mathrm{K}^{+}$and $\mathrm{Cl}^{-}$ions to balance the intracellular and extracellular osmolarity values. To induce NLRP3 activation, this mechanism of $\mathrm{K}^{+}$ions depletion additionally requires an influx of $\mathrm{Ca}^{2+}$ through TRP channels and activation of the kinase TAK1. NLRP3-activating $\mathrm{K}^{+}$ionophores produce a net $\mathrm{K}^{+}$ efflux through different mechanisms. The peptide gramicidin can insert itself into plasma membranes, forming pores that are permeable to monovalent cations. This enables an exchange of intracellular $\mathrm{K}^{+}$for extracellular $\mathrm{Na}^{+}$. Valinomycin, a neutral ionophore, is a cell-permeant compound that can bind to $\mathrm{K}^{+}$ions, replacing the hydration shell of this cation. Consequently, $\mathrm{K}^{+}$ions shielded by valinomycin molecules can pass across the plasma membrane without a requirement for opening a $\mathrm{K}^{+}$-permeable pore. Nigericin is a carboxylic ionophore that can bind to $\mathrm{H}^{+}$or to $\mathrm{K}^{+}$. Both the $\mathrm{H}^{+}$- and $\mathrm{K}^{+}$-bound forms of nigericin are plasma membrane permeant. In this way, nigericin mediates $\mathrm{K}^{+}$transport from the compartment with higher $\mathrm{K}^{+}$concentration to the compartment with lower $\mathrm{K}^{+}$concentration, concomitantly leading to a transient acidification of cytosol. In further stages, the increased cytosolic $\left[\mathrm{H}^{+}\right]$can stimulate $\mathrm{Na}^{+} / \mathrm{H}^{+}$exchangers to extrude $\mathrm{H}^{+}$ions from the cytosol, which is accompanied by $\mathrm{Na}^{+}$influx ${ }^{90}$. Lysosomal damage caused by particulate materials or by other factors requires $\mathrm{K}^{+}$efflux to induce NLRP3 activation, but it is unknown which factors are involved in this $\mathrm{K}^{+}$depletion pathway. 
cell. A similar scenario can be predicted in the case where cells are incubated in a $\mathrm{K}^{+}$-free medium, which was also demonstrated to activate the NLRP3 inflammasome ${ }^{5}$, because $\mathrm{K}^{+}$-free media act as $\mathrm{Na}^{+} / \mathrm{K}^{+}$-ATPase inhibitors ${ }^{15}$. Finally, a distinct mechanism of $\mathrm{K}^{+}$ efflux is involved in NLRP3 activation by low-osmolarity media ${ }^{16}$. Here, the regulatory volume decrease (RVD) response leads to a concerted efflux of $\mathrm{K}^{+}$and $\mathrm{Cl}^{-}$ions in an attempt to equilibrate intracellular and extracellular osmolarities ${ }^{17}$. In this particular case, however, $\mathrm{K}^{+}$efflux does not seem to be sufficient for NLRP3 inflammasome activation, and an additional influx of $\mathrm{Ca}^{2+}$ ions into the cytosol is required ${ }^{16}$ (further discussed below).

\section{Molecular events occurring downstream of $\mathrm{K}^{+}$efflux}

While depletion of intracellular $\mathrm{K}^{+}$is required for NLRP3 activation, little is known about how the change in $\left[\mathrm{K}^{+}\right]_{\mathrm{i}}$ is sensed and how this information is further transduced to the inflammasome. Recently, an important development has helped to solve this question, as NEK7, a Ser/Thr kinase involved in mitotic cell division, has been identified as a factor specifically required for NLRP3 inflammasome activation downstream of $\mathrm{K}^{+}$efflux ${ }^{18-20}$. In response to NLRP3 activators, NEK7 is recruited to NLRP3 upstream of inflammasome formation (in a manner independent of ASC and caspases-1/11). NEK7 can also be detected in NLRP3/ASC specks, and formation of high-molecular-weight NLRP3 complexes that occurs upstream of ASC specking requires that NEK7 interacts with NLRP3. The NLRP3-NEK7 interaction is dependent on $\mathrm{K}^{+}$ efflux and can be blocked by high $\left[\mathrm{K}^{+}\right]_{\mathrm{e}}{ }^{18}$. Interestingly, the catalytic activity of NEK7 is required neither for its binding to NLRP3, nor for the activation of the NLRP3 inflammasome ${ }^{18,20}$.

The requirement for NEK7 in NLRP3 activation restricts this process to cells in interphase. At the endogenous level of NEK7, NLRP3 activators are able to enhance the interaction between NLRP3 and NEK7 in LPS-primed interphase cells but not in cells that have entered mitotic division, and LPS-primed interphase cells show a significantly higher level of caspase- 1 activation than do their mitotic counterparts. Of note, NEK7 overexpression partially restores the responses to NLRP3 stimuli in mitotic cells, suggesting that the endogenous amount of NEK7 is not sufficient to simultaneously participate in both cell division and NLRP3 activation ${ }^{20}$.

It remains unknown how NEK7 is recruited to NLRP3 in response to a decrease in $\left[\mathrm{K}^{+}\right]_{\mathrm{i}}$ and whether elevating the interaction between NLRP3 and NEK7 above a certain threshold is sufficient to trigger the NLRP3 inflammasome assembly. In partial response to the first question, it was found that stimulation with ATP increases NEK7 phosphorylation $^{20}$. This increase could be blocked with N-acetylcysteine, a scavenger of reactive oxygen species (ROS) that also potently inhibits IL- $1 \beta$ release upon stimulation with $\operatorname{ATP}^{5,20,21}$. However, it has not been clearly demonstrated that the enhanced phosphorylation of NEK7 is required for its interaction with NLRP3 and for NLRP3 inflammasome activation. Furthermore, shRNA-mediated silencing of NEK9, a kinase that interacts with NEK7 and causes its activation ${ }^{22}$, does not inhibit NLRP3 activation $^{18}$, suggesting either that NEK7 activation is not required for the NLRP3 inflammasome assembly or that the ROS-dependent NEK7 activation occurs through an as-yet-unidentified mechanism. Further elucidation of this discrepancy and of the detailed mechanism by which NEK7 contributes to NLRP3 activation will be the next important step towards understanding the molecular mechanism of inflammasome assembly.

\section{Differential requirements for $\mathrm{K}^{+}$efflux and NEK7 presence} in autoinflammatory disease-related NLRP3 mutants

Several single amino acid substitutions in NLRP3 are causative for systemic inflammation observed in a spectrum of autoinflammatory diseases known as cryopyrin-associated periodic syndromes (CAPS; cryopyrin being a synonym of NLRP3): neonatal onset multisystem inflammatory disease (NOMID), Muckle-Wells syndrome (MWS), and familial cold autoinflammatory syndrome (FCAS) ${ }^{23}$. Of these, mainly the MWS-associated mutant NLRP3 $3^{\text {R260W }}$ (whose mouse counterpart is Nlrp3 ${ }^{\text {R258W}}$ ) has been studied with respect to the requirement for $\mathrm{K}^{+}$efflux for inflammasome assembly. Interestingly, activation of the Nlrp $3^{\mathrm{R} 258 \mathrm{~W}}$ mutant occurs in macrophages expressing Nlrp $3^{\mathrm{R} 258 \mathrm{~W}}$ in response to extracellular LPS stimulation (independent of any classical triggering stimuli) and without the requirement for $\mathrm{K}^{+}$efflux ${ }^{5}$. However, NEK7 deficiency dramatically reduces the ability of Nlrp $3^{\mathrm{R} 258 \mathrm{~W}}$-expressing macrophages to activate the inflammasome in response to extracellular LPS ${ }^{18}$. NLRP3 ${ }^{\mathrm{G} 775 \mathrm{~A}}$ and NLRP3 ${ }^{\mathrm{G} 775 \mathrm{R}}$ mutants, which are mainly associated with NOMID, show a stronger association with NEK7 than does WT-NLRP3 when overexpressed in HEK293 cells and, conversely, the inflammasome activation-incompetent NLRP3 ${ }^{\mathrm{D} 946 \mathrm{G}}$ mutant associates with NEK7 less strongly ${ }^{20}$. Collectively, these observations suggest that some of the CAPS-causative mutations in NLRP3 could promote inflammasome activation by facilitating the interaction between NLRP3 and NEK7, but such a conclusion requires further elucidation of the mechanism by which NEK7 is involved in the activation of different NLRP3 variants.

\section{Non-canonical NLRP3 activation by caspase-11 involves $\mathrm{K}^{+}$efflux}

Murine caspase-11 and its human orthologues caspases-4 and -5 are cytosolic LPS sensors ${ }^{24}$ that, upon recognition of their ligand, trigger non-canonical inflammasome activation ${ }^{25}$. This process consists of pyroptotic cell death that is independent of the canonical NLRP3 inflammasome components ${ }^{26}$ and NLRP3-, ASC-, and caspase-1-dependent IL-1 $/$ /IL-18 processing and secretion ${ }^{25}$. Recent studies demonstrated that NLRP3 activation downstream of caspase- 11 is mediated by $\mathrm{K}^{+}$efflux ${ }^{27,28}$. This process is initiated by caspase-11-mediated cleavage of pannexin- ${ }^{26}$, a plasma membrane-resident channel permeable to molecules and ions with a molecular weight of up to $\sim 1 \mathrm{kDa}^{29}$. Two molecular events follow the proteolytic processing of pannexin-1: (a) $\mathrm{K}^{+}$efflux (a direct NLRP3 stimulus that induces mIL- $1 \beta$ secretion) and (b) release of ATP, which in turn acts as an agonist of P2X7R to promote cell death $^{26}$. Surprisingly, the levels of ATP released from cells upon caspase- 11 activation and proposed to activate P2X7R are much lower (nanomolar concentrations) than the amounts of ATP typically required to activate this receptor when added as an exogenous stimulus $^{30}$. The mechanism by which intracellular LPS recognition increases macrophage sensitivity to extracellular ATP is not yet identified.

Another effector mechanism of caspase-11 activation involves proteolytic cleavage of a cytosolic protein, gasdermin $\mathrm{D}^{31-33}$. The 
signaling pathways activated upon cleavage of gasdermin D are unknown, but it was demonstrated that, while overexpression of full-length gasdermin D, or of gasdermin D C-terminal fragment, does not cause any apparent changes in cell physiology, expression of gasdermin D N-terminal fragment alone is highly cytotoxic ${ }^{32}$. This observation evinces that the $\mathrm{N}$-terminal fragment of gasdermin $\mathrm{D}$ is one of the downstream effectors of caspase-11. Important questions to be answered in further investigation of the role of gasdermin $\mathrm{D}$ in non-canonical inflammasome activation are whether overexpression of the gasdermin D N-terminal fragment is sufficient to activate the NLRP3 inflammasome and whether this process involves $\mathrm{K}^{+}$efflux. As gasdermin $\mathrm{D} \mathrm{N}$-terminal fragment alone is sufficient to cause pyroptosis, which is associated with plasma membrane disruption, it could be envisaged that this also leads to $\mathrm{K}^{+}$depletion.

Similar to pannexin- $1^{26}$, gasdermin D is required for both cell death and IL- $1 \beta$ release in response to intracellular LPS ${ }^{32,33}$. While IL-1 $\beta$ secretion observed under conditions of intracellular LPS stimulation is dependent on NLRP3, pyroptosis elicited by intracellular LPS only depends on pannexin- ${ }^{26}$ and gasdermin $\mathrm{D}^{32,33}$ and is unaffected in NLRP3-deficient cells. The recent discoveries on the caspase-11 effector mechanisms leading to non-canonical inflammasome activation and to pyroptosis are summarized in Figure 2. Future studies should address the questions of whether-and howthe caspase-11-mediated events (pannexin-1 and gasdermin D

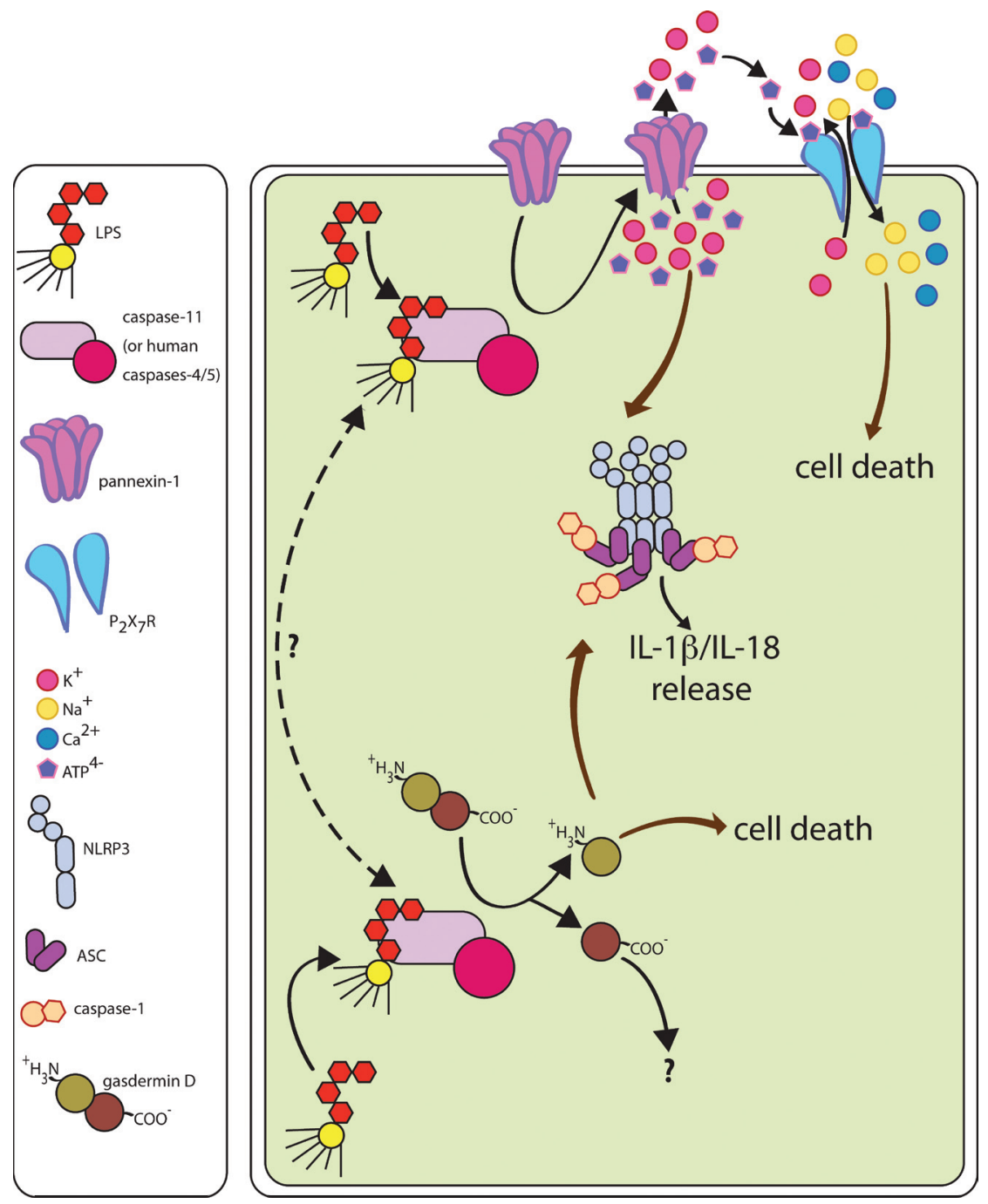

Figure 2. Noncanonical NLRP3 activation by cytosolic LPS. Upon recognition of LPS in the cytosol, caspase-11 cleaves pannexin-1 and gasdermin D. Cleavage of pannexin-1 leads to opening of the channel and leakage of $\mathrm{K}^{+}$and ATP from the cell into the extracellular space. This efflux of $\mathrm{K}^{+}$ions activates the NLRP3 inflammasome, causing proteolytic processing and secretion of IL-1 13 . Simultaneously, ATP acts as an agonist for the P2X7R, leading to NLRP3 inflammasome-independent pyroptotic cell death. Proteolytic cleavage of gasdermin D produces a highly toxic N-terminal fragment of this protein, which mediates both activation of the NLRP3 inflammasome (with subsequent IL-1 $\beta$ processing and secretion) and NLRP3-independent pyroptotic cell death. The relationship between two caspase-11 effectors, pannexin-1 and gasdermin D, is currently not understood. 
proteolytic processing) converge to orchestrate pyroptotic cell death. In particular, the mechanism by which gasdermin D $\mathrm{N}$-terminal fragment induces cytotoxicity will have to be resolved, and the potential role of pannexin- 1 cleavage in this process will have to be investigated more closely. Furthermore, there is a proposed mechanism by which the caspase-11/pannexin-1/NLRP3 axis triggers IL-1 $\beta / \mathrm{IL}-18$ secretion ${ }^{26}$, but it remains unknown how gasdermin $\mathrm{D}$ is involved in this process.

Adding to our knowledge on canonical inflammasome activation, active caspase-1, alongside caspase-11, was also demonstrated to cleave gasdermin $\mathrm{D}^{32}$. In response to activators of various canonical inflammasomes, gasdermin D-deficient macrophages exhibit delayed kinetics of cell death ${ }^{32}$ and decreased levels of secreted IL-1 $\beta^{31-33}$, which suggests that caspase-1-catalysed proteolysis of gasdermin D is one of the effector mechanisms of pyroptosis and that it may contribute to non-classical cytokine secretion.

\section{Mechanisms of NLRP3 activation independent of $\mathrm{K}^{+}$efflux}

Recently, it was reported that inhibition of glycolysis by targeting enzymes that catalyze two of the late reactions of this pathway, glyceraldehyde-3-phosphate dehydrogenase (GAPDH) or $\alpha$-enolase, is sufficient to elicit inflammasome activation in an NLRP3-dependent manner ${ }^{34}$. The proposed sequence of events consists of a decrease in cellular $[\mathrm{NADH}] /\left[\mathrm{NAD}^{+}\right]$ratio, and a consequent increase in the levels of mitochondrial ROS, which, it is suggested, are involved in NLRP3 activation ${ }^{35,36}$. Interestingly, supplementation with the glycolytic metabolite pyruvate (which is normally produced downstream of the inhibited steps of glycolytic cascade) or with succinate (one of the TCA cycle metabolites; both pyruvate and succinate can enhance TCA cycle activity) leads to a decrease in the level of both generated mitochondrial ROS and NLRP3 inflammasome activation ${ }^{34}$. Such an observation suggests that in this pathway mitochondrial ROS act as NLRP3 stimuli. This mechanism of NLRP3 activation is uncommon because it does not require $\mathrm{K}^{+}$efflux: inhibition of GAPDH and $\alpha$-enolase can trigger assembly of the NLRP3 inflammasome at supraphysiological $\left[\mathrm{K}^{+}\right]_{\mathrm{e}}^{34}$. Of note, NLRP3 activation under conditions of disrupted glycolytic flux could have profound pathophysiological significance as, for example, macrophages infected with Salmonella typhimurium exhibit decreased levels of $\mathrm{NADH}^{34}$. Given that infection with $S$. typhimurium is an activator of the NLRP3 inflammasome ${ }^{37}$ and that $S$. typhimurium-mediated NLRP3 activation can be abrogated by pyruvate supplementation ${ }^{34}$, this metabolic signature may constitute an important signal in inflammasome activation.

Of note, it has been demonstrated that efficient glycolysis is required for NLRP3 activation by canonical $\mathrm{K}^{+}$-depleting stimuli ${ }^{38}$. Furthermore, the metabolic changes resulting from inhibition of glycolysis were not observed in cells treated with nigericin, a canonical $\mathrm{K}^{+}$efflux-dependent NLRP3 activator $^{34}$, suggesting that the newly discovered pathway is a distinct mechanism of NLRP3 activation rather than simply an event occurring downstream of cellular $\mathrm{K}^{+}$depletion. In further support of this conclusion, canonical activation of the NLRP3 inflammasome with stimuli such as nigericin or ATP cannot be inhibited by supplementation with pyruvate $^{34}$. It remains unknown whether the NLRP3 inflammasome assembly in response to glycolysis inhibitors relies on a NEK7dependent mechanism. However, this is unlikely in light of the observations that (a) the interaction between NEK7 and NLRP3 requires $\mathrm{K}^{+}$efflux and (b) the $\mathrm{K}^{+} / \mathrm{H}^{+}$ionophore nigericin does not inflict metabolic changes resembling those caused by inhibition of glycolysis.

Another mechanism of NLRP3 activation independent of $\mathrm{K}^{+}$efflux is observed in monocytes but is restricted to several species (e.g. humans or pigs) and not observed in murine cells. For this mechanism of NLRP3 activation, termed "alternative inflammasome activation", extracellular LPS is a stimulus sufficient to elicit mature IL-1 $\beta$ release but not to cause ASC speck formation or pyroptosis. LPS acts as an agonist of TLR4, leading to engagement of the adaptor protein TRIF and of the RIPK1-FADD-caspase-8 signaling cascade, culminating in caspase- 1 activation in an NLRP3- and ASC-dependent manner ${ }^{39}$. The specific nature of the signaling events that drive alternative NLRP3 activation as well as the fact that this mechanism does not lead to the generation of ASC specks may collectively suggest an involvement of a distinct, $\mathrm{K}^{+}$efflux-independent active NLRP3 conformation in this process.

\section{$\mathrm{Ca}^{2+}$ influx is not sufficient, and may not be required, for NLRP3 activation}

Based on the ability of certain NLRP3 stimuli to increase cytosolic $\left[\mathrm{Ca}^{2+}\right]\left(\left[\mathrm{Ca}^{2+}\right]_{i}\right)$, and on the inhibitory effect that several smallmolecule compounds targeting intracellular $\mathrm{Ca}^{2+}$ have on NLRP3 activation, it was proposed that $\left[\mathrm{Ca}^{2+}\right]_{\mathrm{i}}$ ions could be involved in NLRP3 activation ${ }^{40-42}$. The major mechanisms of $\left[\mathrm{Ca}^{2+}\right]_{\mathrm{i}}$ increase in the cytosol are (a) $\mathrm{Ca}^{2+}$ influx from the lumen of endoplasmic reticulum (ER) through a ligand-gated ion channel called inositol trisphosphate $\left(\mathrm{IP}_{3}\right)$ receptor $\left(\mathrm{IP}_{3} \mathrm{R}\right)$, a downstream effector of the phospholipase C (PLC) family, and (b) entry of extracellular $\mathrm{Ca}^{2+}$ ions through plasma membrane-resident $\mathrm{Ca}^{2+}$ channels ${ }^{43}$. Important $\mathrm{Ca}^{2+}$-buffering organelles are (c) mitochondria, which can either absorb or release $\mathrm{Ca}^{2+}$ under different conditions ${ }^{44}$. All of these pathways have been implicated in the activation of NLRP3. In favor of the hypothesis that the ER-derived $\mathrm{Ca}^{2+}$ ions could be a stimulus of NLRP3, a range of small-molecule $\mathrm{IP}_{3} \mathrm{R}$ antagonists and PLC inhibitors have been consistently demonstrated to inhibit activation of the NLRP3 inflammasome ${ }^{40-42}$. However, the observed levels of inhibition vary between the different studies, and in some cases the applied concentrations of small-molecule compounds required to inhibit NLRP3 significantly surpass their $\mathrm{IC}_{50}$ values reported for other processes ${ }^{45,46}$. Furthermore, artificially increasing $\left[\mathrm{Ca}^{2+}\right]_{\mathrm{i}}$ with thapsigargin, an inhibitor of the sarcoplasmic/endoplasmic reticulum $\mathrm{Ca}^{2+}$-ATPase (SERCA; an ion pump transporting $\mathrm{Ca}^{2+}$ from the cytosol into the ER lumen, responsible for maintaining the steep $\left[\mathrm{Ca}^{2+}\right]$ gradient between the ER lumen and the cytosol) either inhibits $^{40}$ or does not influence ${ }^{47}$ NLRP3 activation, demonstrating that translocation of $\mathrm{Ca}^{2+}$ ions into the cytosol is not sufficient to trigger that process. Of note, thapsigargin was demonstrated to elicit modest IL- $1 \beta$ secretion from LPS-primed human macrophages, but it is not known whether the mature form of the cytokine is secreted and whether this process is mediated by NLRP $3{ }^{48}$. Furthermore, thapsigargin was demonstrated to cause NLRP3 activation by inducing ER stress, but the role of $\mathrm{Ca}^{2+}$ in this process has not been studied ${ }^{49}$. 
The current evidence for the involvement of extracellular $\mathrm{Ca}^{2+}$ in the activation of NLRP3 strongly suggests that this pool of $\mathrm{Ca}^{2+}$ does not play a role in the inflammasome assembly. Supporting this is the observation that all tested canonical NLRP3 stimuli that act by depleting cytosolic $\mathrm{K}^{+}$can activate the inflammasome in $\mathrm{Ca}^{2+}$-free extracellular buffers ${ }^{47,50}$. In several studies, a contradictory effect of extracellular $\mathrm{Ca}^{2+}$ depletion was reported ${ }^{40,48}$ but, in some cases at least, such observations may have resulted from simultaneous application of BAPTA-AM and $\mathrm{Ca}^{2+}$-free buffer ${ }^{48}$, which can be expected to interfere with $\mathrm{Ca}^{2+}$ fluxes deriving from a range of different sources. Nevertheless, there is currently no convincing explanation as to why in certain experimental systems the removal of extracellular $\mathrm{Ca}^{2+}$ seems to inhibit NLRP3, while in other setups such treatment does not interfere with NLRP3 activation. A second argument supporting the claim that extracellular $\mathrm{Ca}^{2+}$ is not required for the NLRP3 inflammasome activation comes from the observation that $\mathrm{K}^{+}$ionophores elicit NLRP3 inflammasome assembly in the absence of any significant changes in $\left[\mathrm{Ca}^{2+}\right]_{i}{ }^{47}$. Surprisingly, one study reports that human macrophages can secrete IL-1 $\beta$ in response to ionomycin, a $\mathrm{Ca}^{2+}$ ionophore, but, similar to the case of thapsigargin, the involvement of NLRP3 is not proven and it is not demonstrated that the released form of the cytokine is proteolytically processed ${ }^{48}$.

Interestingly, in the NLRP3 response to hypotonic environments, extracellular $\mathrm{Ca}^{2+}$ influx through mechanosensitive TRP channels and consequent activation of the kinase TAK1 were both demonstrated to be required for activation of the inflammasome alongside RVD-mediated $\mathrm{K}^{+}$efflux ${ }^{16}$. It is unknown whether this mechanism also contributes to inflammasome assembly by all NLRP3 stimuli, but it is suggested that TAK1 is involved in NLRP3 activation induced by lysosomal damage ${ }^{51}$. Finally, one study proposed that $\mathrm{Ca}^{2+}$ influx into the cytosol follows $\mathrm{K}^{+}$efflux caused by NLRP3 stimuli and that this $\mathrm{Ca}^{2+}$ flux promotes activation of the inflammasome by enhancing mitochondrial ROS generation ${ }^{52}$. However, there are two major limitations to this conclusion. First, the only method applied for targeting cytosolic $\mathrm{Ca}^{2+}$ was cell loading with BAPTAAM, which may exert numerous off-target effects ${ }^{53}$. Secondly, the only tested NLRP3 activator was ATP, a cation channel opener and inducer of PLC (through interaction with P2Y2 receptor $^{54}$ ), which makes it challenging to dissect the relative contributions of the various ion fluxes in the process of inflammasome activation.

The mitochondrial $\mathrm{Ca}^{2+}$ stores are the most difficult to perturb experimentally, and consequently their potential role in NLRP3 activation is not well understood. Several reports suggest that an increased $\mathrm{Ca}^{2+}$ uptake by the mitochondria may promote mitochondrial damage and NLRP3 responses ${ }^{40,55,56}$, although it was also demonstrated that mitochondrial damage inflicted by canonical NLRP3 activators is at least in part dependent on NLRP3 and caspase- $1^{57}$. The transporter responsible for mitochondrial $\mathrm{Ca}^{2+}$ uptake during NLRP3 activation by the membrane attack complex (a component of the complement cascade) and by Pseudomonas aeruginosa has been identified as mitochondrial $\mathrm{Ca}^{2+}$ uniporter $(\mathrm{MCU})^{5,56}$. The specific factors that could tie an increase in mitochondrial $\left[\mathrm{Ca}^{2+}\right]$ to NLRP3 inflammasome assembly have not been identified, and it remains unknown whether MCU is involved in NLRP3 responses to its classical, better-characterized activators.

The collective evidence regarding the role of $\mathrm{Ca}^{2+}$ in the activation of NLRP3 suggests that elevation in $\left[\mathrm{Ca}^{2+}\right]_{\text {i }}$ is not required for the assembly of this inflammasome. However, a modulatory role for this ion cannot be excluded, especially in light of two puzzling observations: (a) inhibition of NLRP3 responses by BAPTA-AM ${ }^{41,47}$ and (b) inhibition of NLRP3 activation by siRNA knock-down of a $\mathrm{G}_{\mathrm{q}} \alpha$-coupled G-protein-coupled receptor (GPCR) called $\mathrm{Ca}^{2+}$-sensing receptor $(\mathrm{CaSR})^{42}$. Given that BAPTA-AM has off-target effects apart from scavenging $\mathrm{Ca}^{2+}$ ions inside the cell ${ }^{53}$ and that $\mathrm{Ca}^{2+}$ ions are not the only ligand of $\mathrm{CaSR}^{58}$, reevaluation of the mechanisms by which application of BAPTA$\mathrm{AM}$ or suppression of CaSR signaling interfere with NLRP3 activation could provide valuable insights into the molecular events that regulate NLRP3 inflammasome assembly. We further discuss some aspects of GPCR/CaSR signaling below.

\section{Physiological and pharmacological modulation of NLRP3}

The relevance of NLRP3 in human pathologies has led to research regarding both the intrinsic mechanisms that limit inflammasome activation and the possibility of pharmacological targeting of NLRP3. Even though such studies are challenging, because it is unclear how the $\mathrm{K}^{+}$efflux is transduced to NLRP3, they have nevertheless resulted in discoveries that processes such as cAMP signaling and autophagy can interfere with NLRP3 activation and in identification of several classes of exogenous small-molecule compounds that can act as specific inhibitors of NLRP3 activation.

\section{Inhibition of the NLRP3 inflammasome by cAMP}

In recent years, the interest in how GPCRs could regulate NLRP3 responses resulted in an observation that increasing $[\mathrm{cAMP}]_{\mathrm{i}}$ inhibits the activation of the NLRP3 inflammasome ${ }^{42}$. Specifically, treating cells with pharmacological activators of adenylyl cyclases ${ }^{42}$, or with agonists of GPCRs that enhance adenylyl cyclase activity ${ }^{59,60}$, leads to a decrease in NLRP3 activation in response to classical NLRP3 stimuli. Conversely, NLRP3 stimuli were demonstrated to decrease $[\mathrm{cAMP}]_{i}^{42}$, although it is currently not clear whether this decrease occurs upstream or downstream of NLRP3 activation. One study suggested that inhibition of adenylyl cyclase enzymatic activity (surprisingly, using KH7, an inhibitor targeting the GPCRindependent soluble adenylyl cyclase and not acting on the GPCRregulated transmembrane adenylyl cyclases ${ }^{61}$ ) might be sufficient to activate the NLRP3 inflammasome ${ }^{42}$, but this result could not be reproduced, possibly due to differences in the applied concentrations of the compound ${ }^{60}$. Of note, inhibitors of transmembrane adenylyl cyclases also do not act as NLRP3 inflammasome activators, pointing to a modulatory role of $[\mathrm{cAMP}]_{\mathrm{i}}$ rather than its decrease being the direct NLRP3 stimulus.

Pharmacological targeting of various cAMP-binding proteins that act as downstream effectors of adenylyl cyclase activation revealed that the inhibitory effect that cAMP exerts on NLRP3 activation cannot be ascribed to the currently known cAMP targets ${ }^{42,59,60}$. In 
the study that identified cAMP as a regulator of NLRP3, it was proposed that NLRP 3 could form a complex with cAMP ${ }^{42}$, and recently it was demonstrated that the NLRP3-cAMP complex recruits ubiquitin ligase MARCH7, which in turn labels NLRP3 for degradation in autophagosomes ${ }^{60}$. It is suggested that this process down-regulates NLRP3 signaling. Nevertheless, there are still open questions about the mechanism of inhibition of NLRP3 responses by cAMP. This model suggests a direct interaction between cAMP and NLRP3, in which the nucleotide-binding domain (NBD) of NLRP3 is involved ${ }^{42}$. However, sequence analysis of NLRP3-NBD does not suggest the presence of a cyclic nucleotide-binding fold along with the ATP-binding site ${ }^{62}$. Furthermore, even if the cAMPbinding and ATP-binding sites were in fact the same structural interface, it is not likely that cAMP could compete with ATP for binding to NLRP3, given that in living cells $[\mathrm{ATP}]_{i}^{63,64}$ is much higher than $[\mathrm{cAMP}]_{i}{ }^{65}$. Another problematic aspect of studies on the influence of cAMP on activation of NLRP3 is the consistent use of $\mathrm{KH}^{59,60}$, the inhibitor of soluble, GPCR-independent adenylyl cyclases ${ }^{66}$, to interfere with events that, it is proposed, occur downstream of GPCR-responsive transmembrane adenylyl cyclases. Applying genetic rather than pharmacological approaches to the studies on the influence of cAMP on NLRP3 activation and a more thorough investigation of the roles of established cAMPbinding proteins in this process could potentially provide a greater insight into the mechanism of NLRP3 response inhibition by cAMP.

\section{Regulation of inflammasome responses by autophagy}

Autophagy is emerging as a central process regulating multiple inflammasome responses at several levels. Pro-IL-1 $\beta$ can be degraded in autophagosomes, leading to decreased inflammatory responses to a range of stimuli ${ }^{67}$. In addition, it is also proposed that autophagy specifically controls NLRP3 activation over other characterized inflammasomes. Suppression of the autophagic processes impairs homeostatic turnover of mitochondria, promoting mitochondrial damage that contributes to caspase-1 activation in response to $\mathrm{ATP}^{68}$, as well as in the NLRP3 response to influenza A virus infection ${ }^{69}$. A decrease in the number of autophagosomes was also reported in response to palmitate, a long-chain fatty acid previously demonstrated to activate NLRP $3^{70}$. However, activation of NLRP3 using nigericin or crystalline stimuli enhanced autophagy, ${ }^{71}$ targeting inflammasome components for degradation in the autophagosomes. Collectively, these observations suggest that reduction in the autophagic processing of cellular contents may support NLRP3 inflammasome responses. Conversely, increased autophagy may act as a regulator of the NLRP3 inflammasome specifically and a regulator of IL-1 $\beta$-based inflammation generally by a negative feedback loop. The recent discoveries that dopamine decreases cellular responses to NLRP3 activators by targeting this inflammasome sensor protein for degradation in autophagosomes ${ }^{60}$ and that NF- $\mathrm{KB}$ signaling can inhibit activation of NLRP3 by stimulating the autophagic turnover of dysfunctional mitochondria ${ }^{72}$ demonstrate that this regulatory mechanism can position immune cells towards a state of decreased sensitivity to NLRP3 stimuli even before they encounter inflammasome activators. The proposed mechanisms of regulation of NLRP3 responses by autophagy and by cAMP (discussed earlier) are summarized in Figure 3.

\section{Inhibition of the NLRP3 inflammasome by compounds} containing a sulfonylurea moiety

The first observation that compounds containing a sulfonylurea moiety potently inhibit ATP- or hypotonicity-induced IL-1 $\beta$ processing and release predates the discovery of inflammasomes ${ }^{73}$. This phenomenon was later recognized as specific inhibition of the NLRP3 inflammasome ${ }^{74}$, and until now virtually all validated NLRP3 activators are sensitive to sulfonylurea-containing compounds, such as glyburide or CP-456,773 75 . Sulfonylurea drugs seem to specifically inhibit the triggering step of NLRP3 activation without affecting the NF- $\kappa \mathrm{B}$ signaling-related priming step or the activation of other inflammasomes ${ }^{74,75}$. Compounds containing sulfonylurea moieties have been tested, as NLRP3 inhibitors, in several animal inflammatory disease models, usually with encouraging results ${ }^{75-79}$. Of note, alternative inflammasome activation (described in more detail above) can also be blocked by CP- $456,773^{39}$.

The mechanism by which sulfonylurea compounds inhibit NLRP3 activation is currently not understood. Given that an important target of these pharmaceuticals are $\mathrm{K}^{+}$channels ${ }^{80-82}$ and that $\mathrm{K}^{+}$ efflux is required for NLRP3 activation ${ }^{5}$, one concept would be that sulfonylureas could impede $\mathrm{K}^{+}$efflux from cells treated with NLRP3 stimuli. However, not all sulfonylurea drugs can inhibit inflammasome activation ${ }^{74}$ and, conversely, sulfonylurea compounds were demonstrated not to prevent $\mathrm{K}^{+}$efflux caused by NLRP3 activators $^{75}$, which collectively suggests that these inhibitors act downstream of $\mathrm{K}^{+}$depletion and that the inhibition mechanism is not related to the activity of these compounds on $\mathrm{K}^{+}$channels. Glyburide was shown to inhibit the ATPase activity of NLRP3, but it is unclear whether other drugs from this class can act in a similar manner, and if this observation is related to the glyburidemediated inhibition of inflammasome formation. CP-456,773 $\left(\mathrm{CRID}^{83}\right.$, which has recently been renamed to $\left.\mathrm{MCC}^{850} 0^{75}\right)$ has been demonstrated not to affect the $\mathrm{Ca}^{2+}$ flux in cells treated with $\mathrm{ATP}^{75}$, which, some studies suggest, plays a role in NLRP3 activation $^{40}$. The influence of $\mathrm{CP}-456,773$ on other molecular events connected to NLRP3 activation, such as the production of ROS, decrease in $[\mathrm{cAMP}]_{i}$, or recruitment of NEK7 to NLRP3, has not yet been tested.

Attempts to identify the molecular target of CP-456,773 showed that this compound interacts with proteins from the glutathione S-transferase family ${ }^{83}$, but so far none of these have been shown to transduce the information about $\mathrm{K}^{+}$efflux to the NLRP3 inflammasome. There is conflicting evidence regarding the ability of sulfonylurea drugs to inhibit the activation of CAPS-related NLRP3 mutants, as glyburide has been shown not to affect IL-1 $\beta$ release from cultured monocytes from an FCAS-affected patient ${ }^{74}$, but CP-456,773 suppressed mutant NLRP3 activation in both the 

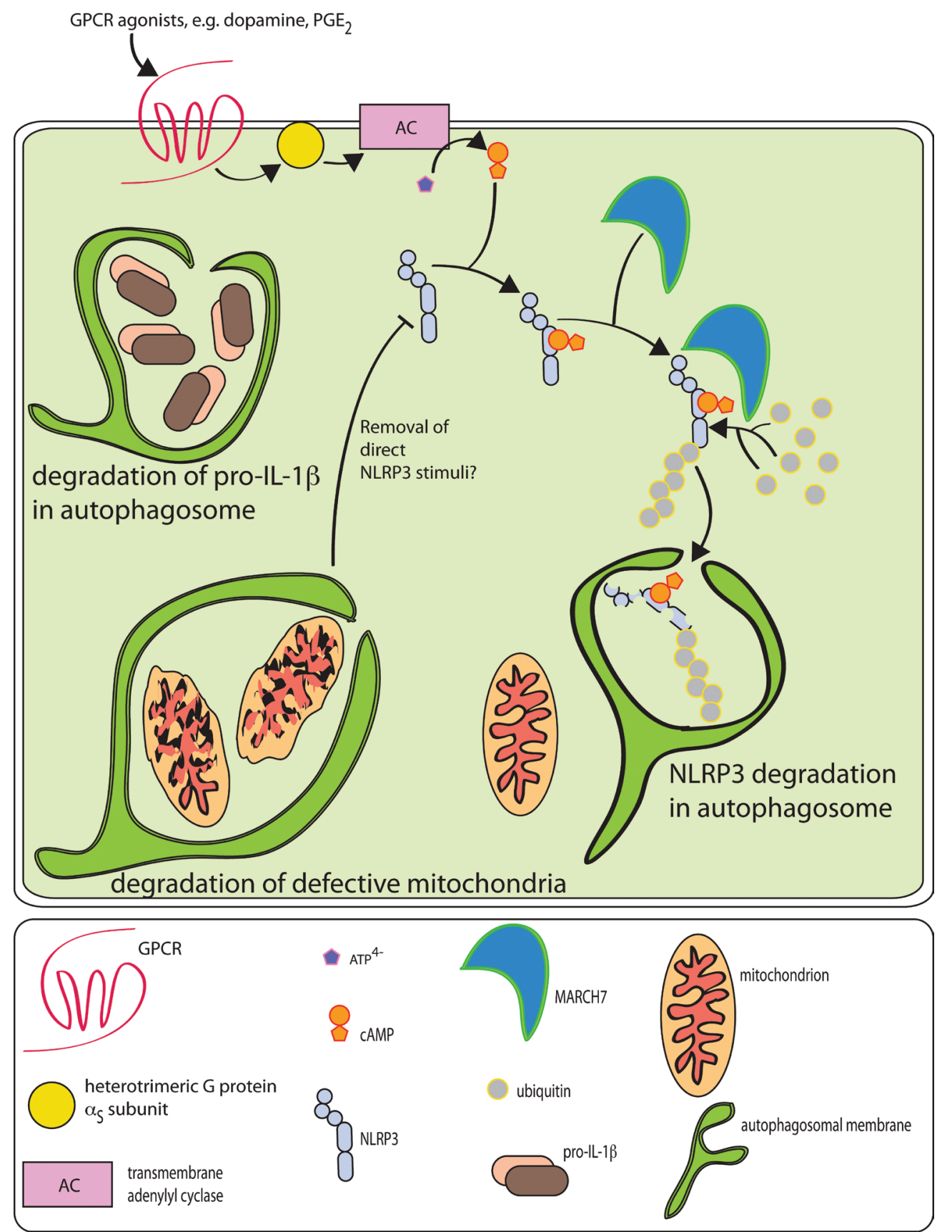

Figure 3. Modulation of the NLRP3 inflammasome by cAMP and autophagy. Several physiological mechanisms regulate NLRP3 responses on the cellular level. Agonists of $\mathrm{G}_{\mathrm{s}}$-coupled GPCRs stimulate the generation of cAMP by transmembrane adenylyl cyclases. cAMP is believed to bind to the nucleotide-binding domain of NLRP3. This formed NLRP3-cAMP complex recruits the ubiquitin ligase $\mathrm{MARCH} 7$ that polyubiquitinates NLRP3, targeting it for autophagosomal degradation. Autophagosomes are also the organelles responsible for degradation of pro-IL-1 $\beta$ (the inactive pro-form of the proinflammatory cytokine IL-1 $\beta$ ), which is a more general mechanism controlling the inflammatory responses mediated by a range of inflammasomes. Finally, mitophagy is a way to dispose of damaged mitochondria that starts with sequestering them in autophagosomes. Autophagosomal degradation of dysfunctional mitochondria curbs the inflammasome responses, possibly by removing the source of direct NLRP3 activators. 
mouse model of MWS and in monocytes from an MWS-affected patient ${ }^{75}$. The NLRP3 mutants investigated in these studies had different amino acid substitutions, which, together with other differences in the experimental systems, could have led to this apparent discrepancy. A more comprehensive study addressing the sensitivity of a range of hyperactive NLRP3 mutants to sulfonylurea compounds could provide more insight into whether these drugs can inhibit inflammasome activation by these protein variants and what the mechanism of inhibition could be.

\section{Inhibition of the NLRP3 inflammasome by cysteine- modifying compounds}

Several recent studies demonstrated that NLRP3 activation can be abolished by pre-treatment of cells with various compounds that contain a Michael acceptor group (a double $\mathrm{C}=\mathrm{C}$ bond in the $\alpha$ position with respect to a carbonyl $[-\mathrm{C}=\mathrm{O}]$ or a nitro group $\left.\left[-\mathrm{NO}_{2}\right]\right]^{84,85}$. In biological systems, these compounds can covalently modify protein Cys residues that are not engaged in disulfide bond formation $^{86,87}$. This mechanism explains the inhibition of the NLRP3 inflammasome both by compounds that are generally regarded as NLRP3 inhibitors (e.g. parthenolide and BAY 11-7082) ) $^{85}$ and compounds whose ability to inhibit NLRP3 activation has been identified as an "off-target" effect (e.g. the Syk kinase inhibitor 3,4-methylenedioxy- $\beta$-nitrostyrene $[\mathrm{MNS}])^{84}$. Importantly, the issue of specificity of the tested inflammasome inhibitors has also been addressed in the cited studies and, while MNS and BAY 11-7082 have been demonstrated to selectively inhibit NLRP3, parthenolide was also able to block other inflammasome responses $^{84,85}$. This observation is probably related to parthenolidemediated direct inhibition of caspase- $1^{85}$ (which contains a Cys residue that is essential for its catalytic activity and which can also be modified by Michael acceptors ${ }^{87}$ ).

In further investigation of the mechanism of NLRP3 inhibition by Cys-modifying compounds, two consecutive structureactivity relationship studies demonstrated that Michael acceptors with very diverse chemical structures can interfere with NLRP3 activation (assessed by IL- $1 \beta$ release and pyroptotic LDH release $)^{88,89}$. Of note, these compounds are capable of inhibiting NLRP3 ATPase activity ${ }^{88,89}$. Furthermore, several Michael acceptors moderately but significantly inhibit the activation of CAPS-related NLRP3 variants, but their potency on these NLRP3 mutants is lower compared to the inhibitory influence exerted on WT-NLRP3 ${ }^{89}$.

When applying compounds that contain a Michael acceptor moiety to investigate the molecular mechanism of NLRP3 activation, several issues have to be considered. First, the downstream effector of NLRP3 is caspase-1, a Cys protease whose catalytic activity depends on an unmodified, free Cys residue. This implies that Michael acceptors, at high enough concentrations, may obscure various experimental readouts that rely on caspase- 1 activity, such as assessing inflammasome speck formation using the caspase1-targeting FLICA reagent, IL-1 $\beta / \mathrm{IL}-18$ release, or pyroptotic $\mathrm{LDH}$ release, even if the particular compounds-of-interest do not directly interfere with NLRP3 activation. Second, the ability of Michael acceptors to directly interact with NLRP3/modify Cys residues in NLRP3 ${ }^{84,89}$ only suggests, but does not prove, that the NLRP3-Cys modification constitutes the mechanism of inflammasome inhibition by these compounds. Further insights into the structural basis of NLRP3 activation and into the possible influence of Michael acceptors on that process are required to resolve this issue.

\section{Conclusions and future directions}

In recent years, a number of molecular players involved in NLRP3 activation have been identified. Most importantly, the direct interaction of NLRP3 with the kinase NEK7 has been described, and its importance for the assembly of the NLRP3 inflammasome has been demonstrated. Major progress has also been made in our understanding of how intracellular LPS triggers caspase-11, leading to proteolytic processing of pannexin- 1 and gasdermin $\mathrm{D}$, and to non-canonical NLRP3 inflammasome activation. Finally, the mechanism by which human monocytes activate NLRP3 in response to extracellular LPS as a single stimulus has been solved and shown to rely on TLR4/TRIF-mediated activation of the RIPK1FADD-caspase- 8 cascade. On the other hand, physiologically relevant mechanisms, such as autophagy and cAMP signaling, have been proposed to down-regulate the activation of NLRP3, demonstrating the physiological importance of limiting NLRP3 inflammasome responses.

However, there still remain unanswered questions about the molecular events that link cytosolic $\mathrm{K}^{+}$depletion to NLRP3-/ NEK7-dependent inflammasome formation. Furthermore, the discovery of the dual function of gasdermin D (as a downstream effector of caspase-11 required for non-canonical NLRP3 activation and a substrate of inflammatory caspases required for pyroptosis) calls for closer investigation of the mechanism of action of this protein. In light of the reported $\mathrm{K}^{+}$effluxindependent modes of NLRP3 triggering that include alternative NLRP3 inflammasome activation and NLRP3 inflammasome activation upon inhibition of glycolysis, the relative contributions of these pathways to inflammatory responses will have to be evaluated. Finally, the mechanisms by which compounds containing sulfonylurea or Michael acceptor moieties cause NLRP3 inhibition will have to be defined, which may open new possibilities for potential future therapeutic applications of these molecules.

\section{Author contributions}

TP wrote the manuscript and prepared the figures. MSM edited the manuscript and provided valuable discussions and criticism. TP, MSM, and EL critically read, analyzed, and discussed the primary sources and conceived the outline of the manuscript.

\section{Competing interests}

The authors declare that they have no competing interests.

\section{Grant information}

The author(s) declared that no grants were involved in supporting this work.

\section{Acknowledgements}

We would like to thank Dr Dagmar Wachten, the Leader of the Max Planck Research Group Molecular Physiology, for helpful discussions on the signaling mechanisms involved in activation of the NLRP3 inflammasome. 
1. Perregaux D, Barberia J, Lanzetti AJ, et al:: IL-1 beta maturation: evidence that mature cytokine formation can be induced specifically by nigericin. $J$ Immunol. 1992; 149(4): 1294-303.

PubMed Abstract

2. Perregaux D, Gabel CA: Interleukin-1 beta maturation and release in response to ATP and nigericin. Evidence that potassium depletion mediated by these agents is a necessary and common feature of their activity. J Biol Chem. 1994; 269(21): 15195-203.

PubMed Abstract

3. Walev I, Reske K, Palmer M, et al.: Potassium-inhibited processing of IL-1 beta in human monocytes. EMBO J. 1995; 14(8): 1607-14. PubMed Abstract | Free Full Text

4. F Mariathasan S, Weiss DS, Newton K, et al:: Cryopyrin activates the inflammasome in response to toxins and ATP. Nature. 2006; 440(7081): 228-32. PubMed Abstract | Publisher Full Text | F1000 Recommendation

5. $\quad F$ Muñoz-Planillo R, Kuffa $P$, Martínez-Colón $G$, et al:: $\mathbf{K}^{+}$efflux is the common trigger of NLRP3 inflammasome activation by bacterial toxins and particulate matter. Immunity. 2013; 38(6): 1142-53.

PubMed Abstract | Publisher Full Text | Free Full Text | F1000 Recommendation

6. F Martinon F, Pétrilli V, Mayor A, et al:: Gout-associated uric acid crystals activate the NALP3 inflammasome. Nature. 2006; 440(7081): 237-41. PubMed Abstract | Publisher Full Text | F1000 Recommendation

7. $F$ Hornung $V$, Bauernfeind $F$, Halle $A$, et al: Silica crystals and aluminum salts activate the NALP3 inflammasome through phagosomal destabilization. Nat Immunol. 2008; 9(8): 847-56.

PubMed Abstract | Publisher Full Text | Free Full Text | F1000 Recommendation

8. Wright SH: Generation of resting membrane potential. Adv Physiol Educ. 2004; 28(1-4): 139-42.

PubMed Abstract | Publisher Full Tex

9. Niebur E: Electrical properties of cell membranes. Scholarpedia. 2008; 3(6): 7166. Publisher Full Tex

10. Alves LA, de Melo Reis RA, de Souza CA, et al:: The $\mathbf{P} 2 \mathbf{X 7}$ receptor: shifting from a low- to a high-conductance channel - an enigmatic phenomenon? Biochim Biophys Acta. 2014; 1838(10): 2578-87.

PubMed Abstract | Publisher Full Tex

11. Kelkar DA, Chattopadhyay $A$ : The gramicidin ion channel: a model membrane protein. Biochim Biophys Acta. 2007; 1768(9): 2011-25. PubMed Abstract | Publisher Full Text

12. Pressman BC: Biological applications of ionophores. Annu Rev Biochem. 1976 45: $501-30$.

PubMed Abstract | Publisher Full Tex

13. Deng D, Jiang N, Hao SJ, et al.: Loss of membrane cholesterol influences Iysosomal permeability to potassium ions and protons. Biochim Biophys Acta. 2009; 1788(2): 470-6.

PubMed Abstract | Publisher Full Tex

14. Schorn C, Frey B, Lauber K, et al:: Sodium overload and water influx activate the NALP3 inflammasome. J Biol Chem. 2011; 286(1): 35-41.

PubMed Abstract | Publisher Full Text | Free Full Text

15. Churchill PC: Second messengers in renin secretion. Am J Physiol. 1985 249(2 Pt 2): F175-84

PubMed Abstract

16. F Compan V, Baroja-Mazo A, López-Castejón G, et al.: Cell volume regulation modulates NLRP3 inflammasome activation. Immunity. 2012; 37(3): 487-500. PubMed Abstract | Publisher Full Text |F1000 Recommendation

17. Ordaz B, Tuz K, Ochoa LD, et al.: Osmolytes and mechanisms involved in regulatory volume decrease under conditions of sudden or gradual osmolarity decrease. Neurochem Res. 2004; 29(1): 65-72. PubMed Abstract | Publisher Full Text

18. $\mathrm{F}$ He Y, Zeng MY, Yang D, et al.: NEK7 is an essential mediator of NLRP3 activation downstream of potassium efflux. Nature. 2016: 530(7590): 354-7. PubMed Abstract | Publisher Full Text | Free Full Text | F1000 Recommendation

19. F Schmid-Burgk JL, Chauhan D, Schmidt T, et al.: A Genome-wide CRISPR (Clustered Regularly Interspaced Short Palindromic Repeats) Screen Identifies NEK7 as an Essential Component of NLRP3 Inflammasome Activation. J Biol Chem. 2016; 291(1): 103-9.

PubMed Abstract | Publisher Full Text | Free Full Text | F1000 Recommendation

20. F Shi H, Wang Y, Li X, et al.: NLRP3 activation and mitosis are mutually exclusive events coordinated by NEK7, a new inflammasome component. Nat Immunol. 2016; 17(3): 250-8.

PubMed Abstract | Publisher Full Text | Free Full Text | F1000 Recommendation

21. F Juliana C, Fernandes-Alnemri T, Kang S, et al:: Non-transcriptional priming and deubiquitination regulate NLRP3 inflammasome activation. $\mathrm{J}$ Biol Chem. 2012; 287(43): 36617-22.

PubMed Abstract | Publisher Full Text | Free Full Text | F1000 Recommendation

22. F Haq T, Richards MW, Burgess SG, et al:: Mechanistic basis of Nek7 activation through Nek9 binding and induced dimerization. Nat Commun. 2015; 6: 8771

PubMed Abstract | Publisher Full Text | Free Full Text | F1000 Recommendation

23. Broderick L, De Nardo D, Franklin BS, et al:: The inflammasomes and autoinflammatory syndromes. Annu Rev Pathol. 2015; 10: 395-424. PubMed Abstract | Publisher Full Text

24. F Shi J, Zhao $Y$, Wang $Y$, et al:: Inflammatory caspases are innate immune receptors for intracellular LPS. Nature. 2014; 514(7521): 187-92. PubMed Abstract | Publisher Full Text | F1000 Recommendation

25. F Kayagaki N, Warming S, Lamkanfi M, et al.: Non-canonical inflammasome activation targets caspase-11. Nature. 2011; 479(7371): 117-21. PubMed Abstract | Publisher Full Text | F1000 Recommendation

26. F Yang D, He Y, Muñoz-Planillo R, et al:: Caspase-11 Requires the Pannexin-1 Channel and the Purinergic P2X7 Pore to Mediate Pyroptosis and Endotoxic Shock. Immunity. 2015; 43(5): 923-32.

PubMed Abstract | Publisher Full Text | Free Full Text | F1000 Recommendation

27. F Schmid-Burgk JL, Gaidt MM, Schmidt T, et al.: Caspase-4 mediates noncanonical activation of the NLRP3 inflammasome in human myeloid cells. Eur $J$ Immunol. 2015; 45(10): 2911-7.

PubMed Abstract | Publisher Full Text | F1000 Recommendation

28. F Rühl S, Broz P: Caspase-11 activates a canonical NLRP3 inflammasome by promoting $\mathrm{K}^{+}$efflux. Eur J Immunol. 2015; 45(10): 2927-36. PubMed Abstract | Publisher Full Text | F1000 Recommendation

29. $F$ Pelegrin $P$, Surprenant A: Pannexin-1 mediates large pore formation and interleukin-1 beta release by the ATP-gated $\mathbf{P}_{2} \mathrm{X}_{7}$ receptor. EMBO J. 2006 25(21): 5071-82.

PubMed Abstract | Publisher Full Text | Free Full Text | F1000 Recommendation

30. Bartlett R, Stokes L, Sluyter R: The P2X7 receptor channel: recent developments and the use of P2X7 antagonists in models of disease. Pharmacol Rev. 2014; 66(3): 638-75.

PubMed Abstract | Publisher Full Text

31. $\mathrm{F}$ He W, Wan $\mathrm{H}, \mathrm{Hu} \mathrm{L}$, et al:: Gasdermin $\mathrm{D}$ is an executor of pyroptosis and required for interleukin-1ß secretion. Cell Res. 2015; 25(12): 1285-98. PubMed Abstract | Publisher Full Text | Free Full Text | F1000 Recommendation

32. F Kayagaki N, Stowe IB, Lee BL, et al:: Caspase-11 cleaves gasdermin D for non-canonical inflammasome signalling. Nature. 2015; 526(7575): 666-71. PubMed Abstract | Publisher Full Text | F1000 Recommendation

33. F Shi J, Zhao Y, Wang K, et al:: Cleavage of GSDMD by inflammatory caspases determines pyroptotic cell death. Nature. 2015; 526(7575): 660-5. PubMed Abstract | Publisher Full Text | F1000 Recommendation

34. F Sanman LE, Qian Y, Eisele NA, et al.: Disruption of glycolytic flux is a signa for inflammasome signaling and pyroptotic cell death. eLife. 2016; 5 pii: e13663.

PubMed Abstract | Publisher Full Text | Free Full Text | F1000 Recommendation

35. Heid ME, Keyel PA, Kamga C, et al.: Mitochondrial reactive oxygen species induces NLRP3-dependent lysosomal damage and inflammasome activation. $J$ Immunol. 2013; 191(10): 5230-8.

PubMed Abstract | Publisher Full Text | Free Full Text

36. F Zhou R, Yazdi AS, Menu P, et al.: A role for mitochondria in NLRP3 inflammasome activation. Nature. 2011; 469(7329): 221-5. PubMed Abstract | Publisher Full Text | F1000 Recommendation

37. Broz P, Newton K, Lamkanfi M, et al.: Redundant roles for inflammasome receptors NLRP3 and NLRC4 in host defense against Salmonella. J Exp Med. 2010; 207(8): 1745-55.

PubMed Abstract | Publisher Full Text | Free Full Text

38. F Moon JS, Hisata S, Park MA, et al.: mTORC1-Induced HK1-Dependent Glycolysis Regulates NLRP3 Inflammasome Activation. Cell Rep. 2015; 12(1): $102-15$

PubMed Abstract | Publisher Full Text | Free Full Text | F1000 Recommendation

39. F Gaidt MM, Ebert TS, Chauhan D, et al.: Human Monocytes Engage an Alternative Inflammasome Pathway. Immunity. 2016; 44(4): 833-46. PubMed Abstract | Publisher Full Text | F1000 Recommendation

40. Murakami T, Ockinger J, Yu J, et al:: Critical role for calcium mobilization in activation of the NLRP3 inflammasome. Proc Natl Acad Sci U S A. 2012; 109(28): $11282-7$

PubMed Abstract | Publisher Full Text | Free Full Text

41. Rossol M, Pierer M, Raulien N, et al.: Extracellular $\mathrm{Ca}^{2+}$ is a danger signal activating the NLRP3 inflammasome through $\mathrm{G}$ protein-coupled calcium sensing receptors. Nat Commun. 2012; 3: 1329. PubMed Abstract | Publisher Full Text | Free Full Text

42. F Lee G, Subramanian N, Kim Al, et al:: The calcium-sensing receptor regulates the NLRP3 inflammasome through $\mathrm{Ca}^{2+}$ and cAMP. Nature. 2012; 492(7427): 123-7.

PubMed Abstract | Publisher Full Text | Free Full Text | F1000 Recommendation 
43. Clapham DE: Calcium signaling. Cell. 2007; 131(6): 1047-58. PubMed Abstract | Publisher Full Text

44. Walsh $\mathrm{C}$, Barrow $\mathrm{S}$, Voronina $\mathrm{S}$, et al.: Modulation of calcium signalling by mitochondria. Biochim Biophys Acta. 2009; 1787(11): 1374-82. PubMed Abstract | Publisher Full Text

45. Bleasdale JE, Thakur NR, Gremban RS, et al:: Selective inhibition of receptorcoupled phospholipase C-dependent processes in human platelets and polymorphonuclear neutrophils. J Pharmacol Exp Ther. 1990; 255(2): 756-68. PubMed Abstract

46. Maruyama T, Kanaji T, Nakade S, et al.: 2APB, 2-aminoethoxydiphenyl borate, a membrane-penetrable modulator of $\operatorname{Ins}(1,4,5) \mathrm{P}_{3}$-induced $\mathrm{Ca}^{2+}$ release. J Biochem. 1997; 122(3): 498-505. PubMed Abstract | Publisher Full Text

47. F Katsnelson MA, Rucker LG, Russo HM, et al:: $\mathbf{K}^{+}$efflux agonists induce NLRP3 inflammasome activation independently of $\mathrm{Ca}^{2+}$ signaling. $J$ Immunol. 2015; 194(8): 3937-52.

PubMed Abstract | Publisher Full Text | Free Full Text | F1000 Recommendation

48. Rada B, Park JJ, Sil P, et al:: NLRP3 inflammasome activation and interleukin$1 \beta$ release in macrophages require calcium but are independent of calciumactivated NADPH oxidases. Inflamm Res. 2014; 63(10): 821-30. PubMed Abstract | Publisher Full Text | Free Full Text

49. Menu P, Mayor A, Zhou R, et al.: ER stress activates the NLRP3 inflammasome via an UPR-independent pathway. Cell Death Dis. 2012; 3: e261. PubMed Abstract | Publisher Full Text | Free Full Text

50. Brough D, Le Feuvre RA, Wheeler RD, et al:: $\mathrm{Ca}^{2+}$ stores and $\mathrm{Ca}^{2+}$ entry differentially contribute to the release of IL-1 beta and IL-1 alpha from murine macrophages. J Immunol. 2003; 170(6): 3029-36. PubMed Abstract | Publisher Full Text

51. F Okada M, Matsuzawa A, Yoshimura A, et al:: The lysosome rupture-activated TAK1-JNK pathway regulates NLRP3 inflammasome activation. J Biol Chem. 2014; 289(47): 32926-36.

PubMed Abstract | Publisher Full Text | Free Full Text | F1000 Recommendation

52. F Yaron JR, Gangaraju S, Rao MY, et al:: $\mathbf{K}^{+}$regulates $\mathrm{Ca}^{2+}$ to drive inflammasome signaling: dynamic visualization of ion flux in live cells. Cell Death Dis. 2015; 6: e1954.

PubMed Abstract | Publisher Full Text | F1000 Recommendation

53. F Saoudi $Y$, Rousseau B, Doussière J, et al.: Calcium-independent cytoskeleton disassembly induced by BAPTA. Eur J Biochem. 2004; 271(15): 3255-64.

PubMed Abstract | Publisher Full Text | F1000 Recommendation

54. Erb L, Weisman GA: Coupling of $P 2 Y$ receptors to $G$ proteins and other signaling pathways. Wiley Interdiscip Rev Membr Transp Signal. 2012; 1(6): 789-803. PubMed Abstract | Publisher Full Text | Free Full Text

55. Triantafilou K, Hughes TR, Triantafilou M, et al.: The complement membrane attack complex triggers intracellular $\mathrm{Ca}^{2+}$ fluxes leading to NLRP3 inflammasome activation. J Cell Sci. 2013; 126(Pt 13): 2903-13. PubMed Abstract | Publisher Full Text

56. F Rimessi A, Bezzerri V, Patergnani S, et al.: Mitochondrial $\mathrm{Ca}^{2+}$-dependent NLRP3 activation exacerbates the Pseudomonas aeruginosa-driven inflammatory response in cystic fibrosis. Nat Commun. 2015; 6: 6201. PubMed Abstract | Publisher Full Text | F1000 Recommendation

57. F Yu J, Nagasu H, Murakami T, et al:: Inflammasome activation leads to Caspase-1-dependent mitochondrial damage and block of mitophagy. Proc Natl Acad Sci U S A. 2014; 111(43): 15514-9.

PubMed Abstract | Publisher Full Text | Free Full Text | F1000 Recommendation

58. Brennan SC, Thiem $\mathrm{U}$, Roth $\mathrm{S}$, et al.: Calcium sensing receptor signalling in physiology and cancer. Biochim Biophys Acta. 2013; 1833(7): 1732-44. PubMed Abstract | Publisher Full Text

59. F Sokolowska M, Chen L, Liu Y, et al:: Prostaglandin E2 Inhibits NLRP3 Inflammasome Activation through EP4 Receptor and Intracellular Cyclic AMP in Human Macrophages. J Immunol. 2015; 194(11): 5472-87. PubMed Abstract | Publisher Full Text | Free Full Text | F1000 Recommendation

60. $\mathrm{F}$ Yan $\mathrm{Y}$, Jiang $\mathrm{W}$, Liu L, et al:: Dopamine controls systemic inflammation through inhibition of NLRP3 inflammasome. Cell. 2015; 160(1-2): 62-73. PubMed Abstract | Publisher Full Text | F1000 Recommendation

61. Bitterman JL, Ramos-Espiritu L, Diaz A, et al.: Pharmacological distinction between soluble and transmembrane adenylyl cyclases. $J$ Pharmacol Exp Ther 2013; 347(3): 589-98. PubMed Abstract | Publisher Full Text | Free Full Text

62. Rehmann $\mathrm{H}$, Wittinghofer $\mathrm{A}$, Bos $\mathrm{JL}$ : Capturing cyclic nucleotides in action: snapshots from crystallographic studies. Nat Rev Mol Cell Biol. 2007; 8(1): 63-73.

PubMed Abstract | Publisher Full Text

63. Gribble FM, Loussouarn G, Tucker SJ, et al:: A novel method for measurement of submembrane ATP concentration. J Biol Chem. 2000; 275(39): 30046-9.

PubMed Abstract | Publisher Full Text

64. Larcombe-McDouall J, Buttell N, Harrison N, et al.: In vivo $\mathrm{pH}$ and metabolite changes during a single contraction in rat uterine smooth muscle. J Physiol. 1999; 518(Pt 3): 783-90.

PubMed Abstract | Publisher Full Text | Free Full Text
65. lancu RV, Ramamurthy G, Warrier S, et al.: Cytoplasmic cAMP concentrations in intact cardiac myocytes. Am J Physiol Cell Physiol. 2008; 295(2): C414-22. PubMed Abstract | Publisher Full Text | Free Full Text

66. Rahman N, Buck J, Levin LR: pH sensing via bicarbonate-regulated "soluble" adenylyl cyclase (sAC). Front Physiol. 2013; 4: 343. PubMed Abstract | Publisher Full Text | Free Full Text

67. Harris J, Hartman M, Roche C, et al.: Autophagy controls IL-1beta secretion by targeting pro-IL-1 beta for degradation. J Biol Chem. 2011; 286(11): 9587-97. PubMed Abstract | Publisher Full Text | Free Full Text

68. F Nakahira K, Haspel JA, Rathinam VAK, et al:: Autophagy proteins regulate innate immune responses by inhibiting the release of mitochondrial DNA mediated by the NALP3 inflammasome. Nat Immunol. 2011; 12(3): 222-30.

PubMed Abstract | Publisher Full Text | Free Full Text | F1000 Recommendation

69. F Lupfer C, Thomas PG, Anand PK, et al:: Receptor interacting protein kinase 2-mediated mitophagy regulates inflammasome activation during virus infection. Nat Immunol. 2013; 14(5): 480-8.

PubMed Abstract | Publisher Full Text | Free Full Text | F1000 Recommendation

70. Wen H, Gris D, Lei Y, et al.: Fatty acid-induced NLRP3-ASC inflammasome activation interferes with insulin signaling. Nat Immunol. 2011; 12(5): 408-15.

PubMed Abstract | Publisher Full Text | Free Full Text

71. Shi C, Shenderov K, Huang N, et al.: Activation of autophagy by inflammatory signals limits IL-1 $\beta$ production by targeting ubiquitinated inflammasomes for destruction. Nat Immunol. 2012; 13(3): 255-63.

PubMed Abstract | Publisher Full Text | Free Full Text

72. F Zhong Z, Umemura A, Sanchez-Lopez E, et al:: NF-кB Restricts Inflammasome Activation via Elimination of Damaged Mitochondria. Cell. 2016; 164(5): 896-910.

PubMed Abstract | Publisher Full Text | Free Full Text | F1000 Recommendation

73. Perregaux DG, McNiff $\mathrm{P}$, Laliberte $\mathrm{R}$, et al.: Identification and characterization of a novel class of interleukin-1 post-translational processing inhibitors. J Pharmacol Exp Ther. 2001; 299(1): 187-97. PubMed Abstract

74. Lamkanfi M, Mueller JL, Vitari AC, et al:: Glyburide inhibits the Cryopyrin/Nalp3 inflammasome. J Cell Biol. 2009; 187(1): 61-70.

PubMed Abstract | Publisher Full Text | Free Full Text

75. Coll RC, Robertson AAB, Chae JJ, et al:: A small-molecule inhibitor of the NLRP3 inflammasome for the treatment of inflammatory diseases. Nat Med. 2015; 21(3): 248-55.

PubMed Abstract | Publisher Full Text | Free Full Text

76. F Liao J, Kapadia VS, Brown LS, et al.: The NLRP3 inflammasome is critically involved in the development of bronchopulmonary dysplasia. Nat Commun. 2015; 6: 8977

PubMed Abstract | Publisher Full Text | F1000 Recommendation

77. Krishnan SM, Dowling JK, Ling YH, et al:: Inflammasome activity is essential fo one kidney/deoxycorticosterone acetate/salt-induced hypertension in mice. Br J Pharmacol. 2016; 173(4): 752-65.

PubMed Abstract | Publisher Full Text | Free Full Text

78. F Hughes FM, Hill HM, Wood CM, et al:: The NLRP3 Inflammasome Mediates Inflammation Produced by Bladder Outlet Obstruction. J Urol. 2016; 195(5): 1598-605.

PubMed Abstract | Publisher Full Text | Free Full Text | F1000 Recommendation

79. F York JM, Castellanos KJ, Cabay RJ, et al:: Inhibition of the nucleotidebinding domain, leucine-rich containing family, pyrin-domain containing 3 inflammasome reduces the severity of experimentally induced acute pancreatitis in obese mice. Transl Res. 2014; 164(4): 259-69.

pancreatitis in obese mice. Transl Res. 2014; 164(4): 259-69.
PubMed Abstract | Publisher Full Text | Free Full Text | F1000 Recommendation

80. Trube G, Rorsman P, Ohno-Shosaku T: Opposite effects of tolbutamide and diazoxide on the ATP-dependent $\mathrm{K}^{+}$channel in mouse pancreatic beta-cells. Pflugers Arch. 1986; 407(5): 493-9.

PubMed Abstract | Publisher Full Text

81. Sturgess NC, Ashford ML, Cook DL, et al:: The sulphonylurea receptor may be an ATP-sensitive potassium channel. Lancet. 1985; 2(8453): 474-5. PubMed Abstract | Publisher Full Text

82. Henquin JC: Tolbutamide stimulation and inhibition of insulin release: studies of the underlying ionic mechanisms in isolated rat islets. Diabetologia. 1980; 18(2): 151-60.

PubMed Abstract | Publisher Full Text

83. Laliberte RE, Perregaux DG, Hoth LR, et al:: Glutathione s-transferase omega 1-1 is a target of cytokine release inhibitory drugs and may be responsible for their effect on interleukin-1beta posttranslational processing. J Biol Chem. 2003; 278(19): 16567-78.

PubMed Abstract | Publisher Full Text

84. $\mathrm{F}$ He $\mathrm{Y}$, Varadarajan S, Muñoz-Planillo R, et al:: 3,4-methylenedioxy- $\beta$ nitrostyrene inhibits NLRP3 inflammasome activation by blocking assembly of the inflammasome. J Biol Chem. 2014; 289(2): 1142-50. PubMed Abstract | Publisher Full Text | Free Full Text | F1000 Recommendation

85. F Juliana C, Fernandes-Alnemri T, Wu J, et al:: Anti-inflammatory compounds parthenolide and Bay 11-7082 are direct inhibitors of the inflammasome. $J$ Biol Chem. 2010; 285(13): 9792-802.

PubMed Abstract | Publisher Full Text | Free Full Text | F1000 Recommendation 
Yin $\mathrm{C}$, Huo F, Zhang J, et al:: Thiol-addition reactions and their applications in thiol recognition. Chem Soc Rev. 2013; 42(14):

6032-59.

PubMed Abstract | Publisher Full Text

87. Santos MM, Moreira R: Michael acceptors as cysteine protease inhibitors. Mini Rev Med Chem. 2007; 7(10): 1040-50. PubMed Abstract | Publisher Full Text

88. F Cocco M, Garella D, Di Stilo A, et al.: Electrophilic warhead-based design of compounds preventing NLRP3 inflammasome-dependent pyroptosis. J Med
Chem. 2014; 57(24): 10366-82.

PubMed Abstract | Publisher Full Text | F1000 Recommendation

89. F Cocco M, Miglio G, Giorgis M, et al.: Design, Synthesis, and Evaluation of Acrylamide Derivatives as Direct NLRP3 Inflammasome Inhibitors. ChemMedChem. 2016.

PubMed Abstract | Publisher Full Text | F1000 Recommendation

90. Spitzer KW, Vaughan-Jones RD: Regulation of Intracellular pH in Mammalian Cell. In The Sodium-Hydrogen Exchanger. Springer US, 2003; 1-15. Publisher Full Text 


\section{Open Peer Review}

\section{Current Peer Review Status:}

\section{Editorial Note on the Review Process}

Faculty Reviews are review articles written by the prestigious Members of Faculty Opinions. The articles are commissioned and peer reviewed before publication to ensure that the final, published version is comprehensive and accessible. The reviewers who approved the final version are listed with their names and affiliations.

\section{The reviewers who approved this article are:}

\section{Version 1}

\section{George Dubyak}

Department of Physiology and Biophysics, Case Western Reserve University, Cleveland, OH, USA Competing Interests: No competing interests were disclosed.

\section{Pablo Pelegrín}

Murcia's BioHealth Research Institute, University Hospital Virgen de la Arrixaca, Murcia, Spain

Competing Interests: No competing interests were disclosed.

The benefits of publishing with F1000Research:

- Your article is published within days, with no editorial bias

- You can publish traditional articles, null/negative results, case reports, data notes and more

- The peer review process is transparent and collaborative

- Your article is indexed in PubMed after passing peer review

- Dedicated customer support at every stage

For pre-submission enquiries, contact research@f1000.com 